\title{
Study of English Intervening Bilingual Teaching Model in Early Childhood Education
}

\author{
Xiuling Liu \\ Foreign Languages College, Xi'an University, Xi'an Shaanxi, 710065, China
}

Keywords: Immersion, English Teaching, Teaching Methods, Bilingual Education

\begin{abstract}
This paper mainly introduces the early English intervening bilingual teaching model for children. English intervening bilingual teaching in early childhood improves the English level of children a lot, the pragmatic ability, especially the ability of the listening and speaking of English, is significantly improved. Early childhood immersion bilingual teaching takes a variety of effective teaching mode, greatly mobilize the enthusiasm and initiative of the children to learn English, and lay a good foundation for their future.
\end{abstract}

\section{Preface}

Immersion refers to that the second language teaching language acts as a foreign language teaching mode, where the second language refers to English. That is, all or part of the time, the children in the kindergarten, be "immersed" in the second language environment. Teachers only use the second language to face the children, not only to explain the second language in the second language, but also to explain some of the subjects in the second language. Therefore, the second language is not only the content of the teaching, but also the teaching method. The immersion bilingual teaching has changed the traditional single foreign language teaching mode. It puts forward higher requirements for the second foreign language.Effectively combining foreign language teaching with discipline curriculum teaching, and making it possible for children to "soaked" in a second language environment.

\section{Theoretical basis of early immersion bilingual education in preschool}

The critical period for language acquisition hypothesis. The critical period hypothesis is that in a specific environment, human learning language has a critical period, after the sensitive period, the ability of human to obtain the language weakens with the age increasing. Children are in the critical period of language development, especially the key period of the development of voice. In this age, language acquisition is the most easy, the probability of success is relatively large; once more than this age, language acquisition ability is reduced, the probability of success is relatively small. Language psychologist Rainer Berg points out that the critical period of language acquisition is between 4 and 5 years old. If they didn't learn a language before that, then they will not be possible to master the language. He thought that the language of the brain has been built up, and this time the brain's side has occurred. Second language of the same existence of the key period, in the sensitive period, children's language skills, if you get a good development, it is possible to speak second language as well as their mother tongue.

Early immersion bilingual teaching is in accordance with the critical period hypothesis in language acquisition, children are in the critical period of language development, from the beginning of the park, let the children be exposed to English as much as possible, "immersion" in English language environment, English language runs through the daily life of the children in the garden, swim play and teaching activities, so that children make a habit of listening to English, speaking English, and using English thinking. 


\section{English immersion bilingual teaching model in early childhood}

\section{Phonics.}

Phonics refers to when the children see a word in English, he or she can spell the word out of a method according to the letters in the word pronunciation rules. In the United States of kindergarten and school, children from three years old, began to accept the natural Pinyin method of education, this method is the United States to learn their mother tongue method, natural Pinyin learning method also applies to English as a second language learning. Phonics is believed to be the world the fastest, most simple, the most effective English spelling learning method, it with the traditional English learning methods are compared, efficiency improved several times. It only needs to 103 basic pronunciation learning, can make learners see word reading, listening and writing. It is a complete English spelling learning method, spelling is early English learning path, he avoided the trouble for children to learn phonetic, from voice to start directly to learn letters and letter combinations in a word pronunciation rules, through subtle methods in education training children to draw inferences. This study advocates that the first teaching "natural phonetic alphabet", improve the sensitivity of children to English pronunciation, through long-term unremitting learning and the influence of the early immersion environment, gradually let the children master the system of English learning methods. For example, children first through the "bad" "cap" "fat" voice learning, it will "a" to produce the overall sense of understanding, when they encounter "mat" hat "bat" and other similar words will naturally and accurately read.

\section{Total Physical Response(TPR).}

TPR is short for Total Physical Response which is come up by psychologist James. TPR focuses on language learning in the interactive mode, because the learners learn English in a relaxed environment, the effect is better, and the tension, anxiety for English learning is unfavorable. Teachers should try to create favorable conditions, so that children have more opportunities to increase the English language input and language output. The advantage of TPR is to emphasize the interaction between the body, the interaction between teachers and children, so that children learn in the game, to bring English learning into life, and better stimulate their interest in learning English.

The basic principle of TPR : "listen -- do the action" as the main teaching organization form, this is the most obvious characteristics of TPR. In the course of learning, teachers use English to send instructions. First, they make their own actions, then,children understand the corresponding relationship between instruction and action, the teacher says the instruction to make children complete the action, when the children are skilled, so that one of the children with English language instruction, other children to make the appropriate action. In such a game, the child's attention is focused, so they can better grasp the content of the study.

TPR can catch the attention of the students at a draught, attract the students to participate in the classroom activity actively, let them learn English in actual experience. The focus of teaching is to help students understand English, master English, communicate with English, not to correct the mistakes made by children in the process of English learning, only to correct some of the mistakes, teachers should pay attention to the method, do not hurt the child's feelings, so that children can not speak English because of the fear of mistakes. Doing so helps children to eliminate the tension, so that children in a relaxed environment to learn English. TPR activities give full play to the active characteristics of children, let the children comprehend English through TPR activities, master English in the cycle of repeated practice.

\section{Situational teaching method.}

Situation teaching method is to achieve the established teaching objectives, according to the teaching content and characteristics of students, the introduction or creation of the content related to the teaching situation, the students are placed in a specific teaching situation, the students' emotional experience, so as to help students understand the content, activate thinking, so that their active participation in teaching activities, improve teaching effectiveness. The core of situation teaching method is to stimulate students' emotion. Situation creation in accordance with the different ways of the general can have the "physical situation," "the" "role play", "multimedia teaching" and other types. 
Situation A: Physical situation method.

In the kindergarten classroom teaching, the most common situation teaching method is the use of physical. It is the objective things directly in front of children, is one of the most direct, the most simple teaching method, the real situation is the most real, the most natural. For example, in the study of the name of the fruit, the teacher can bring a variety of fruits to the classroom, pointing to one of the fruits, to teach children the fruit of the English word. Such as: apple, pear, peach, grape, banana, orange, watermelon, pineapple, etc.. The child looked at the familiar fruit, there is no strange feeling and rejection, it is willing to follow the teacher to learn the English name of these fruits. After being familiar with all kinds of fruit, the teacher can guide the child:

In this context, the children take the physical as a reference, it is easy to understand the teacher's words, and to imitate and practice the teacher's language , children will automatically generate a lot of relevant language based on the relevant situation, to cultivate their English thinking ability and oral expression ability.

Situation B:Simulation game situation

The simulated game situation is to let the children learn English in the process of playing games. Below is a lesson for children to learn the name of the animal, the teacher prepared a number of game props, made of colored cardboard made of all kinds of animal masks, teachers with different animal masks to teach children the appropriate English name, children look at the very image of the animal mask, it is easy to remember the English name. After the teacher let some of the children with animal masks, other children around a circle of games. The teacher pointed to one of the children in the animal mask and asked the question, and to imitate the animal's voice, the other children answered.

Naughty is the nature of the child, children like to play games, so teachers design such an interesting part of the game, give full play to the nature of the children, learning while playing with, children not only master a variety of animal names and sounds, after the teacher questions over and over, children can naturally palm grip "what 's this? This sentence pattern usage. The simulation of the game scene greatly mobilize the enthusiasm and initiative of children learning English, enhance their knowledge, active classroom atmosphere, improve the teaching effect.

Man's sense is the entrance to knowledge, but also the only way to get knowledge. Situational teaching method to the teaching of vivid, specific situation, so that children in a specific situation in the perception, understanding, the use of English knowledge, from the perception of English to the abstract understanding, and then to the output of English language, shorten the time, improve the learning efficiency. Situational teaching fully mobilize the emotion experience of children, stimulate the imagination and creativity of children, to enable that children participate in classroom activities and entertaining actively.

\section{English picture books reading.}

The picture book is a world famous English picture books in English books, suitable for children reading in 4-8 years old . English picture book story books as the main body, through the performance of English conversation, training their reading habits in English, is rich in the development of the imagination and creativity of children; in reading at the same time, enrich the knowledge of their lives, through the beautiful pictures and vivid and interesting stories, let the children learn English at the same time, but also cultivate aesthetic and English reading and writing ability of the children, and then cultivate their comprehensive cultural literacy and language expression ability. 4 to 8 years old children is in the sensitive period of language, through the story books, imitate and repeat the story, let the children like reading English, experience English reading and have fun.

Whether the language development of children is good or not has close relationship with their literature rich experience, especially in the construction of development of words and grammar, picture books and language development have close relationship, children in learning a language, story books can improve their reading motivation, development of vocabulary and grammar ability, improve listening, speaking, reading and writing ability, provide English story books to children with sufficient comprehensible language input, in the process of reading, children can naturally acquisition of English. English picture story provides not only to the children's natural, real, meaningful English 
language and rich subject matter, and can predict the content and repeat the sentences that can increase the confidence of children reading.

Preschool bilingual teachers can inspire children interest of learning English by telling the story books to them, children got close in the hope that they read the illustrated storybook would feel they were there. The plot of a story books is a complete story, in the storytelling process, teachers can have some exaggerated facial expressions and movements to attract the attention of the children, so that they can be a very good understanding of the story. After mastering, teachers can let the children themselves take a picture book, listen to retelling the story to your partner can also be encourage children to school after the story to listen to mom and dad. Their ability of English language output, and the confidence of their confidence in speaking English. The output of English teachers in the classroom as much as possible, let the children soak in a language rich environment, to encourage children to use English in daily life, their curiosity and learning motivation will be excited, they don't memorize English words and sentence patterns, but flexible use of English, through learning by playing in an interactive way to practice English, learning English has become a kind of fun, a kind of enjoyment.

\section{Conclusion}

The study of English intervening bilingual teaching model in early childhood education provides a new teaching mode and experience for the bilingual teaching of children. Early immersion bilingual teaching mode has great role in promoting language skills of children, cognitive ability and social ability. Similar to the native mode of acquisition, early English immersion teaching model carries out bilingual teaching form, is a gradual infiltration process. Early immersion bilingual teaching is in accordance with the mental age and cognitive characteristics of children, children can understand English, use English, generate English, form a pattern of English thinking. Children can learn and use English as easily as the acquisition of native language in the early immersion bilingual teaching mode.

\section{Acknowledgments}

This paper was the research result of the projects supported by Xi'an Social Science Foundation, and the topic name was A study of English intervening bilingual teaching model in early childhood education in Xi'an area. The project number was 13WL02.

\section{References}

[1] Zhao Lin.The Research Report of English Immersion Teaching of the children. Comparative Education Study,2004(7).

[2] Feng Xia.The environment creation of children's language in English Immersion Teaching. Journal of Xi'an University of Arts and Science(Natural Science Edition),2010(1).

[3] Zhao Wei.An experiment of English immersion approach in kindergarten in Shanghai. Early Childhood Education (Education science edition),2007(6).

[4] Zhao Haiyan,Zhao Lin.Preschool English Immersion Education. Xi'an: Xi'an Jiaotong University press, 2000 